\title{
Autumn Books
}

\section{Who needs Clinical Pharmacology?}

\author{
J R A MITCHELL
}

Like many reviewers before me, I looked first at the cover of the book, then at the list of its 11 authors, all except two of whom are from the Edinburgh school, and then I opened the book at random to get an idea of its style and purpose. I was immediately confronted with the structural formula for digoxin, and as a cardiovascular physician it reawakened in me a lot of old doubts about the relevance of some basic science to clinical medicine.

I am in good company, for as the Nobel Laureate, Macfarlane Burnet said in 1971, the "sciences all continue to provide fascinating employment for those active in research . . . but the detail of the RNA phage's chemical structure, or the place of cyclostomes in the evolution of immunity are typical of today's topics in biological research. Almost none of modern basic research in the medical sciences has any direct or indirect bearing on the prevention of disease or on the improvement of medical care."

The doubts which Burnet and I share can best be illustrated by analogy; if we want to learn to drive, and to have personal mobility for pleasure or work, we would not begin by reading a book on the structural formula of petrol and how to make it, or on the hysteresis curves of the tyres under stress, the metallurgy of the body, or the air flow characteristics of the venturi in the carburettor. We would simply accept that if you pressed the accelerator the engine would deliver more power and we would then want to be told how to use that power to make us safely mobile. Once we were competent we would realise that accidents invariably occur because drivers don't foresee, don't judge, or are influenced by alcohol, rather than because they don't know the definition of brake-horse-power or whether their engine has twin overhead camshafts.

Similarly, in medicine the tragedies arise because doctors don't think, don't communicate clearly, can't be bothered, or are ill, and few problems arise because doctors don't know. In respect of diabetic ketoacidosis, for instance, the Royal College of Physicians inquiry showed that two thirds of the deaths stemmed from inappropriate action by doctors, of which the commonest was the failure to think of the disease and to ask for a sample of urine for testing. I cannot believe that the deaths were due to being unable to remember that insulin "consists of 51 amino acids and has a molecular weight of 6000 . . is made up of two polypeptide chains (designated A \& B) linked by disulphide bridges" or to a lack of knowledge of the molecular mode of its action. Like the driver and his accelerator pedal, all that the practising physician needs to know is that if you give insulin the blood sugar falls, so the main requirement is to diagnose the diabetes, to know how hard to press the insulin pedal so as to drive the blood sugar safely to its destination, to know what the other pedals do, and to know how to read a road map. Any other information about insulin may be fun for the few but is distracting clutter for the many who just want to be safe drivers and not car designers.

If the function of books is to free the mind from clutter, so that if we ever do want to know the structural formula of digoxin we can go to them and look it up, all well and good. The danger is that what is written down may be asked about in examinations. My generation of medical students had to learn the dates of ossification of every epiphysis, and the minute by minute embryology of the human fetus. I have seldom needed to refer back to the books for that information, but because it was in the books it was examined. The tyranny of such anatomical clutter was subsequently recognised, but I suspect the tyranny which elements of biochemical, immunological, microbiological, and pharmacological clutter impose on medical students has not yet been hammered home to curriculum committees. Books to free the mind are fine but they so easily become "set books" so that the students need to know the clutter they contain to pass examinations.

One doubt leads to another, so I must confess to similar uncertainties about the existence of clinical pharmacology as a discrete discipline. I have the uneasy feeling that it is made up of two disparate parts which should have been kept separate rather than being forced together. At one end is the chemistry, kinetics, and mode of action of drugs, and perhaps this should never have been hived off from biochemistry and physiology. In the driving seat there is therapeutics, which cannot be separated from medicine. The difference in approach between these two parts seems to relate to what drugs ought to do in a tidy world (pharmacology) and what they actually do in the real world (medicine and patient based clinical trials). Devotees of the former occasionally seem to regard patients as an untidy nuisance so 
retreat to animal models, to receptor theory, or to pharmacokinetics, whereas the latter say: "If it's safe then let's give it to patients with $\mathrm{X}$ and see if it works."

An example of this schism occurred in our early studies on atenolol where we were told that the drug had to be given twice daily for hypertension because of its kinetics and its time limited ability to modify totally different situations such as postexercise and isoprenaline induced tachycardia. We decided to look at reality and not at the models, and found that once daily treatment sufficed in hypertensive patients. Doubt about the existence of clinical pharmacology may be why the campaign to have a "consultant clinical pharmacologist" on the staff of every district hospital has failed. Moreover, the existing drivers in gastroenterology, oncology, cardiology, and endocrinology may consider that they have a better feel for the vehicles they use than a single general purpose clinical pharmacologist. The small number of appointees to such posts in district general hospitals throughout Britain does not, in my view, reflect apathy or resistance to change but native common sense.

But back to the book which I opened at random, where the main problem is not how to remember the structural formula of digoxin, but how to decide whether a breathless patient really has heart failure, whether digoxin offers benefit outweighing its toxicity to patients in sinus rhythm, and, if so, what doses should be prescribed. As befits a title which is celebrating its twenty fifth edition, this is a workmanlike book so these topics are touched on, but the would be driver is then told that "full details of the use of digoxin cannot be given here," so I suspect that many readers who are not sitting exams will promptly put the book back on their shelves for reference and turn instead to the British National Formulary.

This is an excellent book of its genre because it works its way through antimicrobials, analgesics, drugs acting on the various body systems, vitamins, haematinics, anticoagulants, chemotherapeutic agents, dermatological preparations, and adverse reactions, ending with a "short list" of drugs which could serve as the model for rational prescribing in a hospital or general practice. Each drug or group of drugs has a brief historical background, followed by its pharmacology, mode of use, and a selected reference list for further reading. Bscause prices change faster than textbooks can be produced the authors have omitted any reference to comparative costs.

My doubts, then, are not about this book but whether books on clinical pharmacology are of any help to the men in the driving seat as opposed to the back room boys in the car factories. The main problems in medicine are whether to use something (hypotensives, anticoagulants, cancer chemotherapy) rather than what the drugs are or even how to use them. This is well exemplified by a section on "drugs used in the treatment of hypertension," where, after 18 pages about the drugs, including a fair sprinkling of structural formulae, the driver who is eager to press his foot on the accelerator pedal looks at his where to go road map and reads that "there is no clear cut division between normal arterial pressure and one that would be regarded as being elevated." In the 14 lines that follow no mention is made of actual blood pressure levels, whether systolic or diastolic, that could guide the reader into action, into further inquiry, or to the decision not to prescribe any of the drugs whose characteristics he has just been told. In short, and to paraphrase Richard Doll, such books are for botanists and not gardeners, for astronomers not navigators, and for car designers not drivers. The book is fine, but is clinical pharmacology?

Clinical Pharmacology. 25th edn. Ed Ronald H Girdwood. (Pp 647 £12·50.) Baillière Tindall. 1984.

\title{
Editing a medical textbook
}

\author{
RONALD H GIRDWOOD
}

In 1884 there occurred two events which had a certain amount of influence on my activities in later years. One was that my father was born, and the other was that Dr John Mitchell Bruce, a physician at Charing Cross Hospital, produced a book entitled Materia Medica and Therapeutics.

In $1917 \mathrm{I}$ in turn entered the world just as the Russian Revolution took place, and in that year there was published a reprint of the tenth edition of Dr Bruce's book. When I duly went to school in 1922 Dr Bruce had been joined by W J Dilling as coauthor and the 12th edition was on sale. My own first publication (a limerick in the school magazine) was in 1926, and in the same year Dr Dilling published in the $B M \mathcal{F}$ an article entitled "Some pharmacological effects of lead."

In 1928 we were both in print again. Dr Dilling wrote for the $B M \mathcal{F}$ an article on "Gangrene following the use of ergotized rye bread," and I wrote an article on an unsuccessful journey to the moon entitled "Moonshine." At the time it would have been a lunatic idea for me to imagine that in later years I would be writing about the other kind of moonshine in a successor to the BruceDilling book. In 1928 it was in its 13th edition.

In due course Dr Dilling, now the sole editor, became professor of pharmacology and therapeutics at Liverpool University and the title Pharmacology and Therapeutics of Materia Medica was usually (and not surprisingly) abbreviated to Dilling. Professor Stanley Alstead and his colleagues at the University of Glasgow next took over, and in 1960 the 20th edition appeared, completely rewritten under the title Clinical Pharmacology.

When I retired from my university post in 1982 the departmental files were cleared of non-essential papers and in the 126 bags of waste paper were the early letters dealing with my own personal involvement not only in Clinical Pharmacology, but also in three other books that I had edited in whole or in part from 1969 onwards. Like most editors, I had cut my teeth on the editorial boards of various journals. It must have been about 1973 that I was invited by Professor Alstead to assemble a group to produce a $23 \mathrm{rd}$ edition of Clinical Pharmacology, and he agreed to act as consultant editor.

When a completely new team takes over the preparation of a book it is often simpler to start afresh rather than to rewrite chapters, and this we decided to do, each author submitting a completely new manuscript. The team was a relatively young one. I, perhaps foolishly, undertook to write about a third of the volume, but there is an advantage in that the more an editor writes himself the less he is dependent on others for manuscript when a deadline is approaching or has been passed. At the critical time in addition to departmental and clinical duties I was dean of our faculty of medicine and our 250th anniversary as a faculty was being celebrated, but the book duly appeared in 1976. I no longer have copies of the encouraging, despairing, or threatening letters that I sent out to the authors, or even of the messages of appreciation and thanks which they eventually received. All the work and the typing was done outside university hours. The publication was celebrated with a party and impromptu do it yourself concert. Youth was having its fling and the wives were able to compare notes with their cosufferers.

Family life was not about to return to normal, however, because planning for the 24th edition began almost at once. Some of the correspondence remains. On 5 June $1978 \mathrm{I}$ asked that all manuscript would be in my hands by the beginning of October, and on 2 October I wrote to all contributors stating that I would deliver the 